\title{
Phytoplankton acclimation and spectral penetration of UV irradiance off the central Chilean coast
}

\author{
Vivian Montecino, Gemita Pizarro
}

Departamento de Ciencias Ecológicas, Facultad de Ciencias, Universidad de Chile, Casilla 653, Santiago, Chile

\begin{abstract}
This study of surface and underwater UV irradiance and its effect on phytoplankton photosynthesis was carried out in autumn, winter and spring at coastal and oceanic stations off the coast of central Chile $\left(30^{\circ}\right.$ and $\left.33^{\circ} \mathrm{S}\right)$. At $30^{\circ} \mathrm{S}$ during autumn, $1 \%$ of surface UVB irradiance $(308 \mathrm{~nm})$ reached a minimum depth $\left(Z_{U V_{n} m}\right)$ of $11 \mathrm{~m}$ and a maximum depth of $15 \mathrm{~m}$ without a significant difference between coastal and oceanic areas. In winter, the $Z_{U v 308 \mathrm{~nm}}$ minimum was $15 \mathrm{~m}$ within $80 \mathrm{~km}$ offshore (coastal stations) and the $Z_{\mathrm{UV} 308 \mathrm{~mm}}$ maximum was $17 \mathrm{~m}$ at the oceanic station, $200 \mathrm{~km}$ offshore. UVA $\left(Z_{\text {UV } 380 \mathrm{~nm}}\right)$ reached a minimum of $24 \mathrm{~m}$ and a maximum of $42 \mathrm{~m}$ in autumn, also with no significant spatial trend. In winter, $1 \%$ of this spectral band reached a depth of 32 to $36 \mathrm{~m}$ at the coastal stations (within $80 \mathrm{~km}$ ) and $50 \mathrm{~m}$ at the oceanic station. Photosynthesis $(P)$ versus irradiance $(I)$ experiments carried out on deck, with and without UV irradiance, showed no significant differences in maximum specific photosynthesis $\left(P B_{\text {max }}\right)$. It was also found that on a scale of hours, the microalgae were able to increase the absorbance ratio $330-340 / 665 \mathrm{~nm}$. In vitro during $2 \mathrm{~h}$ incubation under constant photosynthetically available radiation (PAR) plus 10 different levels of UVB, $P B_{\max }$ was significantly inhibited $(>10 \%)$ at a $305 \mathrm{~nm}$ dosage rate of $1 \mu \mathrm{W} \mathrm{cm} \mathrm{cm}^{-2} \mathrm{~nm}^{-1}$ Nevertheless, this amount of UVB never reached deeper than $3 \mathrm{~m}$ into the water column during the period studied at $30^{\circ} \mathrm{S}$. These results suggest that under severe ozone depletion only the upper fraction of the euphotic zone would be under higher UV irradiances and, given an appropriate time (hours) to acclimatize, phytoplankton will be able to cope with this environmental stress.
\end{abstract}

KEY WORDS: Upwelling Chile-Peru Eastern Boundary Current - UV-absorbing compounds

\section{INTRODUCTION}

Solar ultraviolet B (UVB) irradiance has been a significant variable in the aquatic environment throughout evolution (Vincent \& Roy 1993). Phytoplankton have developed defenses to protect their cells from its damaging effect. UV-absorbing compounds (absorbing in the range 310 to $360 \mathrm{~nm}$ ) found in these microalgae (Carreto et al. 1990, Karentz et al. 1991b) act as a natural sunscreen. In addition to these protective mechanisms, phytoplankton are able to recover and repair some damage, e.g. through photorepair. This mechanism of repairing damaged portions of DNA by enzyme activation with blue-green light has been documented by Karentz et al. (1991a).

Subsurface phytoplankton in upwelling areas are suddenly exposed to higher PAR (photosynthetically available radiation) intensities, due to vertical mixing, in an environment where UV is also present (Kullenberg 1982). In this new radiation field, phytoplankton survival depends on their capacity to maintain an optimal photosynthetic rate. Because this key physiological process is affected by UV, phytoplankton must be able to acclimatize, even though surface UV is only $5 \%$ of PAR on a sunny day (Fleischmann 1989). In terms of energy content, UVA reaches an equivalent of about $4 \%$ of the PAR energy input and UVB is equivalent to $20 \%$ of the UVA and $0.8 \%$ of the PAR (Vincent \& Roy 1993).

Photoacclimation has been shown to occur in response to variations in photon flux density and spectral distribution between 400 and $700 \mathrm{~nm}$, and observed changes in primary productivity rates, or pigment concentrations, have been proposed to be related to complex processes in the photosynthetic apparatus (Falkowski \& La Roche 1991). Fixed-depth in situ 
measurements of primary productivity are influenced by UV at the water surface (Lorenzen 1979, Smith \& Baker 1980, Cullen \& Neale 1993), but this varies depending on latitude (Behrenfeld et al. 1993, Helbling et al. 1993). Long-term effects of UV are also mitigated by photoadaptation (Neori et al 1984, Samuelsson et al. 1985, Cullen \& Lewis 1988). It is also known that UV tolerance varies according to species (Jokiel \& York 1984, Karentz et al. 1991a, Vernet et al. 1994).

In order to characterize and assess the relevance of the UV climate in upwelling ecosystems in the ChilePeru Eastern Boundary Current, primary production experiments (carbon fixation) with and without UV were performed. Quantification of photosynthetic pigments and the presence of UV-absorbing compounds (mycosporine-like amino acids, MAAs) was obtained through absorbance measurements from assemblages of phytoplankton.

The experiments were carried out at 2 locations, over a period of $2 \mathrm{yr}$. The first set of experiments was conducted during cruises off the coast of Chile in April. June and October 1992 and the second set of experiments was carried out in March and April 1993 using samples obtained offshore from Montemar (see Fig. 1).

\section{MATERIALS AND METHODS}

This study was carried out off central Chile at 2 upwelling centers reported by Fonseca \& Farías (1987), i.e. Coquimbo and Valparaíso. The upwelling center at $30^{\circ} \mathrm{S}$, shown schematically in Fig. 1, spreads west over 30 to $50 \mathrm{~km}$ (Sergio Salinas pers. comm.) and includes Stns 8,14 and 19.

Measurement of surface and subsurface UV irradiance was performed using PUV-510 and PUV-500 spectroradiometers (Biospherical Instruments, Inc., San Diego, CA, USA), respectively. Each sensor has 1 UVB mean spectral band $(305 \mathrm{~nm}$ and $308 \mathrm{~nm}$ for the surface and underwater sensors, respectively), 3 UVA spectral bands with maxima at 320,340 , and $380 \mathrm{~nm}$ and 1 spectral band for PAR (400 to $700 \mathrm{~nm})$. The sensors were interfaced with a portable computer that collected surface data every $30 \mathrm{~s}$ throughout the day, to obtain daily maximum values and daily integrals for each UV band and PAR. The underwater sensor also measured depth, temperature and natural fluorescence (not shown). Depth profiles were obtained by lowering the PUV-500 unit at a speed of $1 \mathrm{~m} \mathrm{~s}^{-1}$ and collecting data every second.

UV irradiance measurements (corrected following the calibration factors of the manufacturer) were performed at $30^{\circ} \mathrm{S}$, during cruises sponsored by the Joint Global Ocean Flux Studies Project (JGOFS), in autumn (21 to 27 April), winter (22 to 25 June) and spring (24 to

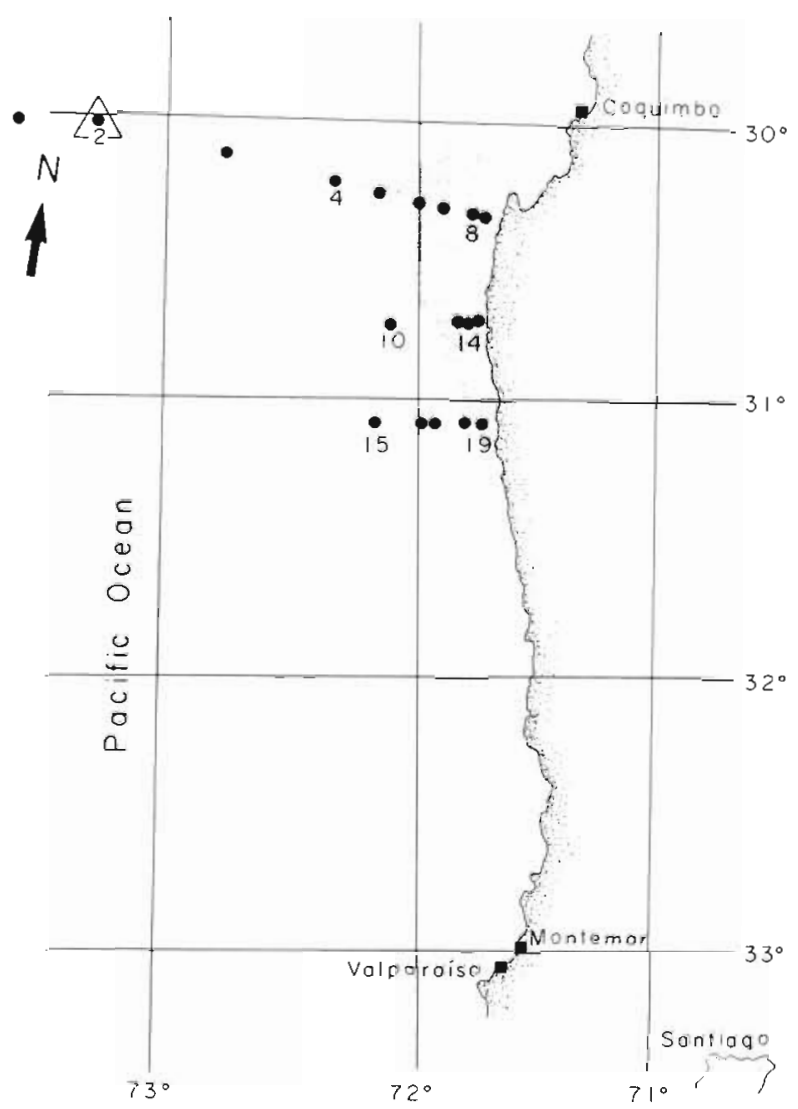

Fig. 1 Location of sampling sites off central Chile. Sampling Stns 2, 4, 8 and 19 are from JGOFS cruises in the $30^{\circ} \mathrm{S}$ upwelling area (shaded)

26 October) 1992. Additional UV irradiance measurements were taken in the second set of experiments at $33^{\circ} \mathrm{S}$ at Montemar (Fig. 1) in early autumn 1993 (5 to 13 March and 22 April). The average daily maximum value for surface UV irradiance was obtained for each period at all sites. To analyse subsurface data, a mean irradiance extinction coefficient $(k)$ for PAR and for each UV band ( $\left.k_{\mathrm{UVnn}}\right)$ was calculated from the depth gradient at each site. A $1 \%$ surface PAR penetration depth $\left(Z_{\text {eu }}\right)$ and a $1 \%$ UV irradiance penetration depth per wavelength $\left(Z_{U V n m}\right)$ were obtained. To compare profiles a test of equality among $k$ regression coefficients was done and examined for significance (Sokal \& Rohlf 1981, Zar 1984).

During the cruises, samples were collected with a Go flo bottle from 7 different depths, 100, 50, 25, 12, 6, 3 , and $1 \%$ of surface irradiance. At Montemar, surface water samples were collected using a bucket. All of the samples were filtered in replicates ( 1 to 2 l) through glass fiber filters (Millipore AP47 or Whatman GF/F). Pigment extraction (chl a) using 90\% acetone was performed on samples taken from all the sites. At some sites, additional samples were extracted in $80 \%$ 
ethanol to test for UV-absorbing compounds (MAAs). After $24 \mathrm{~h}$ in the cold, both extracts were scanned for optical density (absorbance) measurements in a Shimadzu double beam Scanning Spectrophotometer 150-02. Acetone extracts were scanned only in the PAR range (Jeffrey \& Humphrey 1975) and ethanol extracts were scanned for 250 to $700 \mathrm{~nm}$ (Yentsch \& Phinney 1989, Carreto et al. 1990, Karentz et al. 1991a).

Chl a concentration and MAAs absorbance values at different depths were integrated planimetrically for correlation analysis with $k_{\text {PAR }}$ and $k_{u \vee n m}$. This was done for the cruises within the upper $30 \mathrm{~m}$ for chl $a$ and within the upper $15 \mathrm{~m}$ for MAAs.

Primary production experiments, with and without UV, were performed during cruises and also at Montemar.

The first experiment was performed in winter near the coast (June 1992, Stn 19; Fig. 1). Samples (100 ml subsamples from a $10 \mathrm{l}$ sample taken at $2 \mathrm{~m}$ depth) to which $20 \mu \mathrm{Ci}$ of $\mathrm{NaH}^{14} \mathrm{CO}_{3}$ had previously been added were incubated on deck in circulating surface water Replicate samples were exposed to 3 different treatments: total UV treatment in polyethylene bags (>257 nm), UVA treatment in polyethylene bags covered with Mylar ( $>340 \mathrm{~nm}$ ) and without-UV treatment in glass bottles ( $50 \%$ transmission at $380 \mathrm{~nm}$ ). Incubation ( $5.75 \mathrm{~h}$ ) was done in a 5 level light gradient obtained with neutral-density filters: $100,50,22,16$. and $1 \%$ of surface irradiance. Total added radioactivity was determined storing aliquots of the inoculated sample with ethanolamine (Fluka). Dark controls were also included and all samples were filtered through $\mathrm{GF} / \mathrm{F}$ filters. The filters were subsequently fumed with $\mathrm{HCl}$, and a dioxane-based cockail was used for scintillation counting. As part of this first experiment, $500 \mathrm{ml}$ of sample in polyethylene bags was also exposed to UV, uncovered, covered by Mylar or in glass bottles for pigments and MAAs analysis. At the start of the incubation, at least 11 was filtered for each time zero value. The polyethylene bags used during incubation in this experiment were changed to open glass vials covered by the different filters in the autumn experiment, in consideration of the debate about the use of polyethylene bags as sample containers (Holm-Hansen \& Helbling 1993, Prézelin \& Smith 1993)

The following autumn (March and April 1993) a second set of experiments was performed with samples obtained from the Montemar bay ( $33^{\circ} \mathrm{S}$ ). On March 9 . subsamples of $10 \mathrm{ml}$, taken from a $20 \mathrm{l}$ surface water sample, were inoculated with $0.5 \mu \mathrm{Ci}$ of $\mathrm{NaH}^{14} \mathrm{CO}_{3}$ and then exposed to natural irradiance in unstoppered $20 \mathrm{ml}$ vials. These vials were arranged in rows in a tap water circulating incubator, and exposed for $4 \mathrm{~h}$ in a 5 level irradiance gradient: $100,31,19,12$, and $7 \%$ of surface irradiance, obtained using neutral-density screens. The rows of vials were covered with either polyethylene (with-UVB treatment), Mylar (with-UVA treatment) or Plexiglas (>383 nm) in the case of treatment without UV Total added activity was determined on aliquots as above. After exposure, each unfiltered $10 \mathrm{ml}$ sample was fixed in the same incubation vial with $500 \mu l$ buffered formaline. These samples were then acidified with $250 \mu \mathrm{HCl}$ and shaken under a hood. Afterwards, $10 \mathrm{ml}$ of Ready Gel (Beckmann) cocktail was added to each vial.

The experiment was repeated on 22 April using another surface sample from Montemar bay, in a light gradient of 10 intensities $(100,35,25,10,6,3,1.4,0.6$, 0.4 , and $0.3 \%$ of surface irradiance), but with $20 \mathrm{ml}$ subsamples and adding $4 \mu \mathrm{Ci}$ of $\mathrm{NaH}^{14} \mathrm{CO}_{3}$ on each vial and incubating for $2 \mathrm{~h}$. Then the $20 \mathrm{ml}$ was filtered through GF/F filters that were thereafter exposed to $\mathrm{HCl}$ fumes and transferred to counting vials, adding $5 \mathrm{ml}$ of Ecolume (ICN) cocktail.

Later, an experiment was carried out to measure the effect of UV on $P B_{\max }$ (specific photosynthesis at saturating light), using water from the surface sample taken on 22 April that had been stored in the cold and dark for $24 \mathrm{~h}$. A UVB gradient with 10 intensity levels, from $100 \%$ to $1 \%$, was simulated in vitro using a UVB lamp (Q Panel) and neutral-density screens placed on top of unstoppered $20 \mathrm{ml}$ glass vials. Constant PAR $\left(2614 \mu \mathrm{W} \mathrm{cm}^{-2}\right)$ was maintained using a fluorescent lamp placed sideways. A volume of $4 \mu \mathrm{Ci} \mathrm{NaH}{ }^{14} \mathrm{CO}_{3}$ was added to each sample, which were incubated at room temperature for $2 \mathrm{~h}$. Then the samples were filtered using the same process of filtration treatment described above. After adding $10 \mathrm{ml}$ of Ready Gel, radioactivity was measured in a liquid scintillation counter (Beckmann LS 5000 TD).

Photosynthetic parameters and their standard errors were obtained from the $P$ (photosynthesis) versus $I$ (irradiance) curves using the Systat program, fitting the model of Jassby \& Platt (1976). These parameters were compared among treatments and dates using a nonparametric test (Kruskal-Wallis and KolmogorovSmirnov). Thereafter $P B$ was normalized with the calculated $P B_{\max }$ for each curve.

\section{RESULTS}

Absolute mean maximum values of UVB and UVA at the surface are shown in Fig. 2a. At $30^{\circ} \mathrm{S}$, mean maximum $305 \mathrm{~nm}$ irradiance was $3.06 \pm 0.39$ and $3.2 \pm$ $0.59 \mu \mathrm{W} \mathrm{cm}^{-2}$ in spring (April 1992) and summer (January 1994), respectively. The minimum value was $0.63 \pm 0.09 \mu \mathrm{W} \mathrm{cm} \mathrm{cm}^{-2}$ in winter (June 1992). Between seasons, when $305,320,340$, and $380 \mathrm{~nm}$ were normalized to PAR, a change in the spectral composition of 

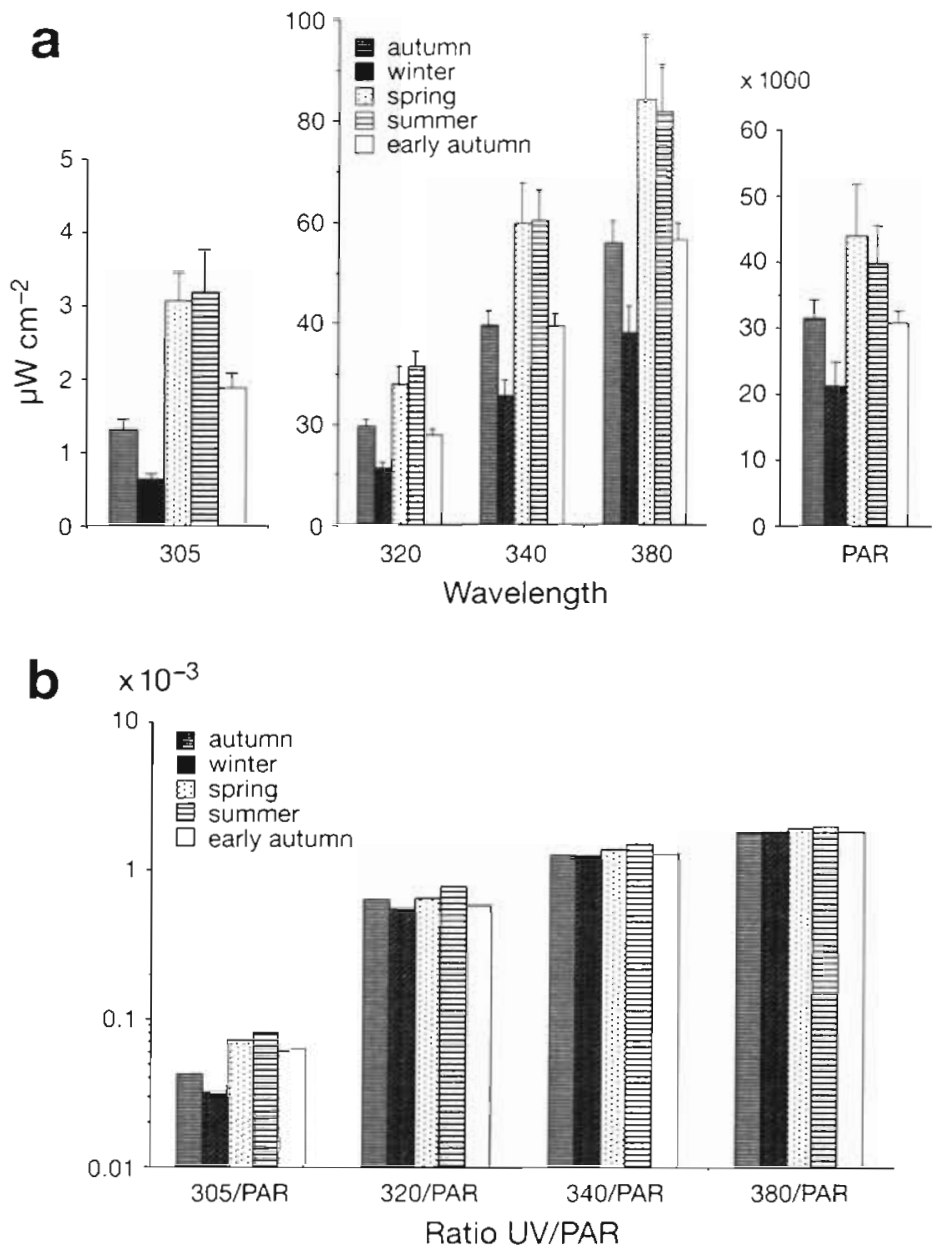

Fig. 2. (a) Mean (+ SE) maximum daily surface UV irradiance $(305,320$, 340 and $380 \mathrm{~nm}$ ) and PAR ( 400 to $700 \mathrm{~nm}$ ) during 4 to $6 \mathrm{~d}$ in autumn (April), winter (June) and spring (October) 1992 cruises. Summer UV and PAR values are the mean maximum measured in January 1994, also at $30^{\circ} \mathrm{S}$. Early autumn (March and April) 1993 values were measured at Montemar $\left(33^{\circ} \mathrm{S}\right)$. (b) UV bands normalized to PAR of same measurements as above

UV irradiance was observed, especially for the proportion of UVB (Fig. 2b). After planimetrically integrating the UVA measured from 320 to $400 \mathrm{~nm}$ and the UVB measured from 305 to $320 \mathrm{~nm}$, the UVB/PAR, UVA/ PAR and UVB/UVA ratios were $0.42,11.30$ and 3.72 , respectively.

Significance among extinction coefficients $(k)$ measured at $30^{\circ} \mathrm{S}$ between 10.30 and $15.30 \mathrm{~h}$ (Table 1) indicates that in autumn there are no differences as a result of distance from the coast (mean $k_{308 \mathrm{~nm}}=0.349 \pm$ $\left.0.012 \mathrm{~m}^{-1}\right) . Z_{U \vee 308 \mathrm{~nm}}$ reached a minimum of $11 \mathrm{~m}$ and a maximum of $15 \mathrm{~m}$. In winter $k_{308 \mathrm{~nm}}$ was significantly different according to the distance from the coast. The $1 \%$ depth minimum was $15 \mathrm{~m}$ within $80 \mathrm{~km}$ offshore coastal stations and the maximum was $17 \mathrm{~m}, 200 \mathrm{~km}$ offshore (oceanic station). UVA $\left(Z_{U V 380 \mathrm{~nm}}\right)$ reached a minimum of $24 \mathrm{~m}$ and a maximum of $42 \mathrm{~m}$ in autumn, also with no significant difference in the spatial pattern. In winter $k_{380 \mathrm{~nm}}$ was significantly different depending on distance from the coast. A total of $1 \%$ of this spectral band reached 32 to $36 \mathrm{~m}$ depth within $80 \mathrm{~km}$ offshore and $51 \mathrm{~m}$ depth at the oceanic station. $k_{308 \mathrm{~nm}}$ was significantly higher in autumn than in winter. For PAR, $Z_{\text {eu }}$ varied between 38 and $62 \mathrm{~m}$ in autumn and between 48 and $102 \mathrm{~m}$ in winter (Table 1).

Integrated chl a values $\left(\int_{0}^{30}\right)$ were highest in autumn in the coastal zone, 45.9 to $50.6 \mathrm{mg}$ chl a $\mathrm{m}^{-2}$ (Table 1), with $\int_{0}^{30} 665 \mathrm{~nm}$ absorbance units of the extracts of 3.23 and 3.93 respectively. The lowest $\int_{0}^{30} \mathrm{chl}$ a values were found at the oceanic

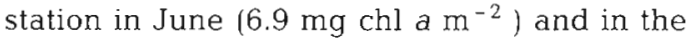
coastal zone in October (8.1 $\mathrm{mg}$ chl a $\mathrm{m}^{-2}$ ) (Table 1); the $\int_{0}^{30} 665 \mathrm{~nm}$ absorbance in these extracts was 0.34 and $1.77 \mathrm{OD} \mathrm{m}^{-2}$ respectively.

Correlations between $\int_{0}^{30} \mathrm{chl} a$ and $\int_{0}^{15} \operatorname{chl} a$ with $k_{308 \mathrm{~nm}}$ were significant $\left(\mathrm{r}^{2}=0.717, \mathrm{p}<\right.$ $0.004 ; r^{2}=0.928, p<0.0001$, respectively) This was not the case for the relationship between $\int_{0}^{30} \operatorname{chl} a$ and the $k$ of the other UV bands nor with the $k$ for PAR. Also, a significant correlation was obtained between UV absorbance peaks found between 330 and $340 \mathrm{~nm}$ (MAAs) in the samples from 0 to $15 \mathrm{~m}$ with $k_{308 \mathrm{~nm}}\left(\mathrm{r}^{2}=0.963, \mathrm{p}<0.018\right)$ and also with $k_{\text {PAR }}\left(\mathrm{r}^{2}=0.921, \quad \mathrm{p}<0.04\right) \quad$ (calculated from Table 1).

Fig. 3 shows a higher amount of MAAs in an autumn sample of $1 \mathrm{~m}$ depth than in a sample from $20 \mathrm{~m}$ depth from the same cast at Stn 19 (27 April), with a difference in the absorbance ratio $330-340 / 665 \mathrm{~nm}$ of $42 \%$. The difference is more remarkable since chl a was higher in the $20 \mathrm{~m}$ sample. This absorbance ratio difference was also obtained experimentally at a coastal station with a $4 \mathrm{~m}$ depth sample, incubated on deck during the cruise of June 1992, and also in April 1993 with a surface sample from Montemar. The exposure period under solar irradiance was $5.75 \mathrm{~h}$ in winter (June) and $2 \mathrm{~h}$ in autumn (April). The total UV was calculated by integrating the $305 \mathrm{~nm}$ radiation dosage rate received during the incubation time $\left(6394\right.$ and $1770 \mu \mathrm{W} \mathrm{cm} \mathrm{cm}^{-2}$ respectively). The increase in MAAs was 20 to $44 \%$ in the June experiment and $118 \%$ in the April experiment, with a decrease in chl $a$ of 44 and $25 \%$ in June and April respectively. The highest $\int_{0}^{15}$ absorbance ratio $330-340 / 665 \mathrm{~nm}$ was found in October. The highest ratio $\mathrm{UV}_{305 \mathrm{~nm}} / \mathrm{PAR}$ was also found in October (Fig. 2b). 
Table 1. Extinction coefficients of UV and PAR; integrated chlorophyll a $\int_{0}^{30}$ and UV absorbance between 330 and $340 \mathrm{~nm}$ integrated in the upper $15 \mathrm{~m}$ from samples of 3 to 5 different depths at different stations at $30^{\circ} \mathrm{S}$. n: number of samples

\begin{tabular}{|c|c|c|c|c|c|c|c|}
\hline $\begin{array}{l}\text { Date } \\
\text { (1992) }\end{array}$ & Stn & $\begin{array}{c}\text { Wave- } \\
\text { length } \\
\text { (nm) }\end{array}$ & $\begin{array}{c}k \\
\left(m^{-1}\right)\end{array}$ & $\pm S E$ & $\begin{array}{c}\text { Chi a } \\
\int_{0}^{30} \\
\text { (mg m } \mathrm{m}^{-2} \text { ) }\end{array}$ & $n$ & $\begin{array}{l}\text { UV absorbance } \\
\text { units } \int_{0}^{15}\end{array}$ \\
\hline \multicolumn{8}{|l|}{ April } \\
\hline \multirow[t]{5}{*}{21} & 8 & 308 & 0.306 & 0.004 & 19.38 & 4 & \\
\hline & & 320 & 0.242 & 0.001 & & & \\
\hline & & 340 & 0.178 & 0.001 & & & \\
\hline & & 380 & 0.112 & 0.001 & & & \\
\hline & & PAR & 0.090 & 0.001 & & & \\
\hline \multirow[t]{5}{*}{24} & 2 & 308 & 0.309 & 0.013 & 16.85 & 3 & \\
\hline & & 320 & 0.286 & 0.006 & & & \\
\hline & & 340 & 0.254 & 0.006 & & & \\
\hline & & 380 & 0.168 & 0.004 & & & \\
\hline & & PAR & 0.122 & 0.002 & & & \\
\hline \multirow[t]{5}{*}{26} & 8 & 308 & 0.420 & 0.013 & 45.90 & 5 & 3.31 \\
\hline & & 320 & 0.293 & 0.005 & & & \\
\hline & & 340 & 0.231 & 0.001 & & & \\
\hline & & 380 & 0.168 & 0.001 & & & \\
\hline & & PAR & 0.102 & 0.001 & & & \\
\hline \multirow[t]{5}{*}{26} & 14 & 308 & 0.421 & 0.013 & 36.48 & 5 & \\
\hline & & 320 & 0.324 & 0.003 & & & \\
\hline & & 340 & 0.205 & 0.004 & & & \\
\hline & & 380 & 0.109 & 0.001 & & & \\
\hline & & PAR & 0.074 & 0.001 & & & \\
\hline \multirow[t]{5}{*}{27} & 19 & 308 & 0.363 & 0.014 & 50.57 & 5 & 2.70 \\
\hline & & 320 & 0.321 & 0.006 & & & \\
\hline & & 340 & 0.264 & 0.003 & & & \\
\hline & & 380 & 0.192 & 0.001 & & & \\
\hline & & PAR & 0.102 & 0.002 & & & \\
\hline \multicolumn{8}{|l|}{ June } \\
\hline \multirow[t]{5}{*}{22} & 2 & 308 & 0.272 & 0.007 & 6.85 & 4 & 0.40 \\
\hline & & 320 & 0.240 & 0.003 & & & \\
\hline & & 340 & 0.180 & 0.001 & & & \\
\hline & & 380 & 0.091 & 0.001 & & & \\
\hline & & PAR & 0.045 & 0.001 & & & \\
\hline \multirow[t]{5}{*}{23} & 4 & 308 & 0.304 & 0.005 & 18.98 & 5 & \\
\hline & & 320 & 0.280 & 0.002 & & & \\
\hline & & 340 & 0.217 & 0.001 & & & \\
\hline & & 380 & 0.144 & 0.000 & & & \\
\hline & & PAR & 0.096 & 0.002 & & & \\
\hline \multirow[t]{5}{*}{24} & 8 & 308 & 0.306 & 0.021 & 12.22 & 5 & \\
\hline & & 320 & 0.268 & 0.003 & & & \\
\hline & & 340 & 0.218 & 0.001 & & & \\
\hline & & 380 & 0.128 & 0.001 & & & \\
\hline & & PAR & 0.070 & 0.001 & & & \\
\hline \multicolumn{8}{|l|}{ October } \\
\hline \multirow[t]{5}{*}{27} & 8 & 308 & 0.318 & 0.012 & 8.10 & 3 & 1.29 \\
\hline & & 320 & 0.272 & 0.003 & & & \\
\hline & & 340 & 0.220 & 0.003 & & & \\
\hline & & 380 & 0.150 & 0.003 & & & \\
\hline & & PAR & 0.077 & 0.001 & & & \\
\hline
\end{tabular}

lowest $P B_{\max }$ values for all the UV treatments were found in June, off Coquimbo (Table 2).

Nonetheless normalized $P B$ (with the calculated $P B_{\text {max }}$ for each curve), showed a difference between treatments in June (Fig. 4) where a reduction of 22 to $29 \%$ was found at higher intensities in the experiment with UV, at PAR irradiance higher than 6000 $\mu \mathrm{W} \mathrm{cm}^{-2}$ (Fig. 4a).

In relation to the effect of different intensities of UV on $P B_{\text {max, }}$ it was found that with a $305 \mathrm{~nm}$ dosage rate

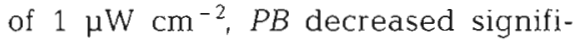
cantly ( $>15 \%)$ after 2 h of incubation (Fig. 5). Above this irradiance a $P B$ relative decrease of $45 \%$ was observed (Fig. 5).

\section{DISCUSSION}

It is extremely difficult to assess the potential impact of UV irradiance on organisms like phytoplankton that not only thrive in a dynamic medium like the ocean, but also possess great physiological plasticity. Throughout evolution, microalgae have coped with UV irradiance by inducing mechanisms to protect against or recover from damage (Vincent \& Roy 1993). Difficulties in quantifying UV effects experimentally are mainly related to the time dependence of photoinhibition and determining the dosage rates or the dose to be used in order to mimic the effect of vertical mixing (Cullen \& Lewis 1988, Cullen \& Lesser 1991). They are also related to the differing sensitivity of phytoplankton taxa (Vernet et al. 1993).

High UV irradiance affects primary productivity (PP) of natural phytoplankton assemblages differently depending on latitude. There is little effect on photosynthetic capacity at low latitudes where UV irradiance is high (Helbling et al. 1992). This situation is reversed at high latitudes, espe-

Despite differences in the experimental settings (polyethylene bags or vials) in the $3 P-I$ experiments with different UV screening, no significant differences were found in $P B_{\max }$ in June, March and April. The cially during ozone depletion (Vernet et al. 1994). The question of the impact of UV irradiation on phytoplankton carbon fixation could be relevant to international programs related to ocean flux studies and is 


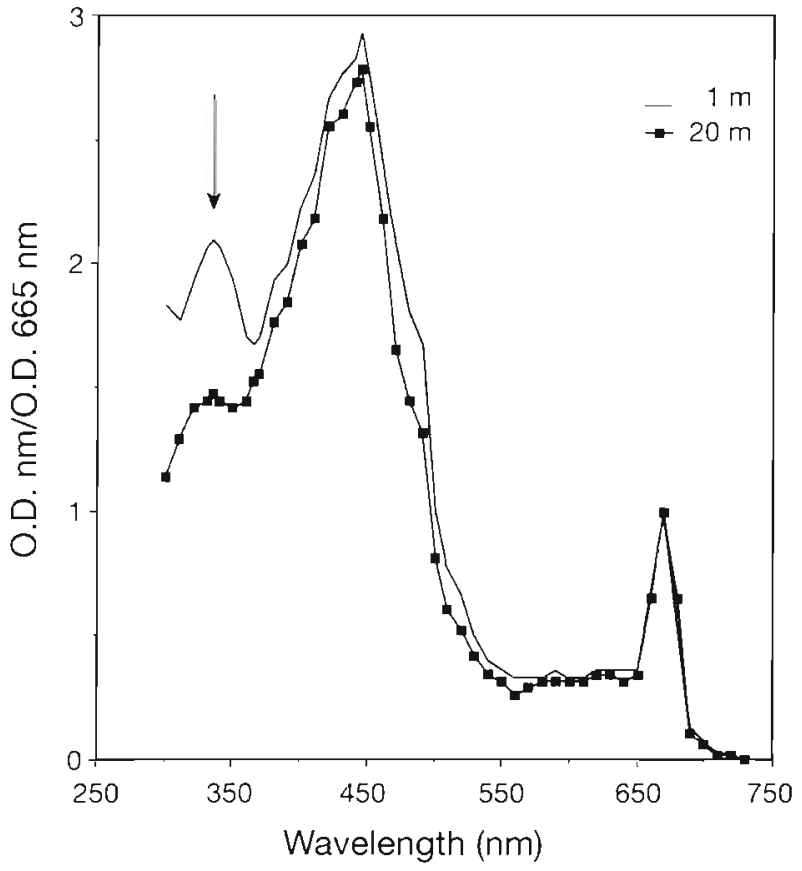

Fig. 3. Relative absorption spectra of ethanol extracts, normalized at $665 \mathrm{~nm}$, from a $1 \mathrm{~m}$ and a $20 \mathrm{~m}$ water sample from the same cast at Stn 19 (27 April 1992). Arrow indicates $42 \%$ difference in the $330-340 / 665$ ratio

crucial when considering methodological protocols, including long-term in situ exposures (i.e. JGOFS) that may well overestimate the PP results at intermediate latitudes.

To mimic ecologically significant UV intensities for PP measurements, this study was carried out mainly under environmental radiation levels and used incu-

Table 2. Photosynthetic parameters ( \pm SE) of $P$-I curves of the different incubation treatments. $P B_{\text {max }}$ : maximum specific photosynthesis at saturating light $\left(\mathrm{mg} \mathrm{C} \mathrm{mg}^{-1} \mathrm{chl} \mathrm{a} \mathrm{h}{ }^{-1}\right) ; I_{\mathrm{k}}$ :

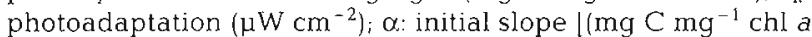
$\left.\left.\mathrm{h}^{-1}\right) /\left(\mu \mathrm{W} \mathrm{cm} \mathrm{cm}^{-2}\right)\right]$

\begin{tabular}{|c|c|c|c|}
\hline & $\begin{array}{c}\text { UVB } \\
>308 \mathrm{~nm}\end{array}$ & $\begin{array}{l}\text { Treatment } \\
\text { UVA } \\
>327 \mathrm{~nm}\end{array}$ & $\begin{array}{c}\text { PAR } \\
>380 \mathrm{~nm}\end{array}$ \\
\hline \multicolumn{4}{|c|}{25 June 1992} \\
\hline$P B_{\max }$ & $6.4 \pm 0.5$ & $6.2 \pm 0.5$ & $7.4 \pm 0.4$ \\
\hline$I_{\mathrm{K}}$ & $676 \pm 369$ & $716 \pm 280$ & $2092 \pm 270$ \\
\hline$\alpha$ & $0.206 \pm 0.106$ & $0.189 \pm 0.068$ & $0.077 \pm 0.008$ \\
\hline \multicolumn{4}{|c|}{9 March 1993} \\
\hline$P B_{\max }$ & $11.8 \pm 0.6$ & $13.5 \pm 0.2$ & $11.423 \pm 0.2$ \\
\hline$I_{\mathrm{K}}$ & $972 \pm 201$ & $1064 \pm 46$ & $1224 \pm 124$ \\
\hline$a$ & $0.263 \pm 0.047$ & $0.277 \pm 0.010$ & $0.203 \pm 0.018$ \\
\hline \multicolumn{4}{|c|}{22 April 1993} \\
\hline$P B_{\text {rndx }}$ & $10.2 \pm 0.6$ & $11.3 \pm 0.6$ & $10.3 \pm 0.6$ \\
\hline$I_{K}$ & $2075 \pm 238$ & $2592 \pm 304$ & $2648 \pm 318$ \\
\hline$\alpha$ & $0.107 \pm 0.009$ & $0.095 \pm 0.008$ & $0.085 \pm 0.008$ \\
\hline
\end{tabular}
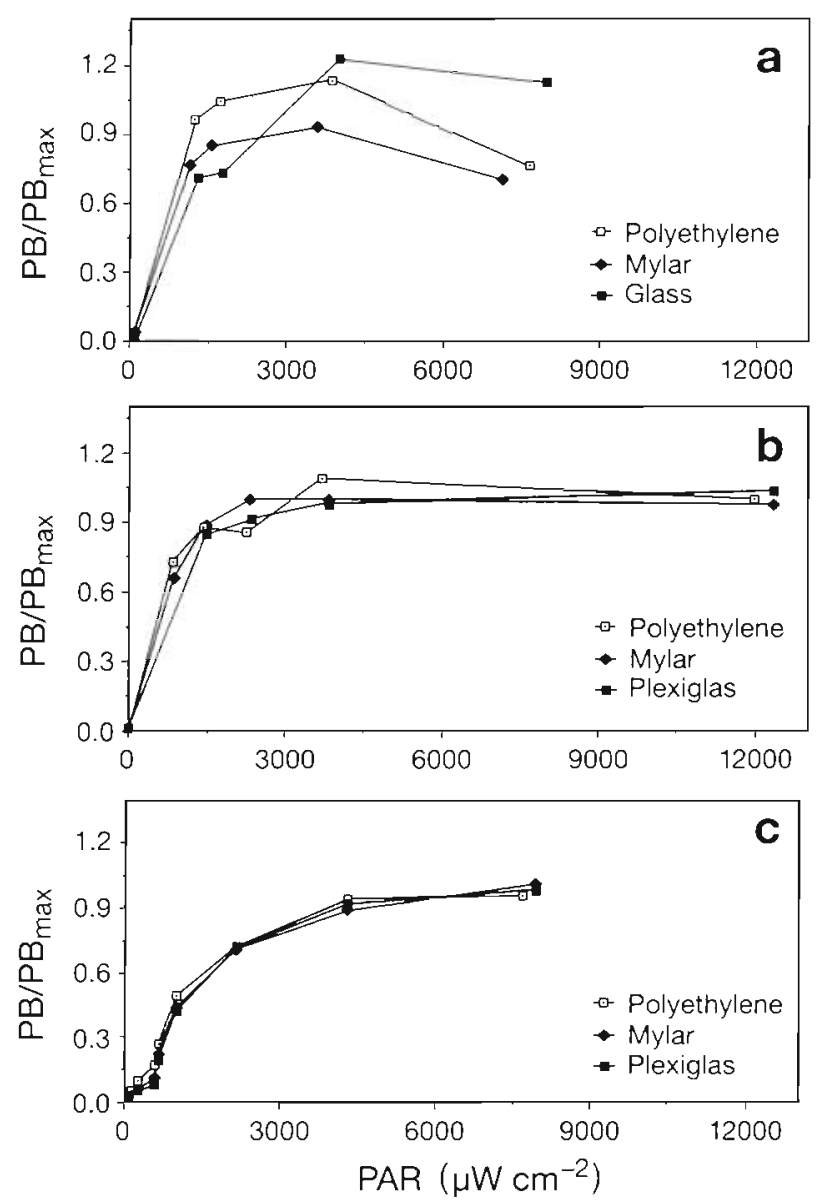

Fig. 4. Relative $P B$ normalized by calculated $P B_{\max }$ from photosynthesis vs irradiance $(P-I)$ experiments performed on deck with different filters (Polyethylene, $>257 \mathrm{~nm}$; Mylar, $>340 \mathrm{~nm}$; glass, $>380 \mathrm{~nm}$; Plexiglas, $>383 \mathrm{~nm}$ ) for UV. (a) 25 June 1992, $2 \mathrm{~m}$ water sample from Stn 19. (b) 9 March 1993, surface sample obtained off Montemar. (c) 22 April 1993. surface sample obtained off Montemar

bation times that were similar to time periods of exposure to UV due to vertical mixing. In upwelling zones, in which phytoplankton are exposed to high PAR for short periods of time, the expected response in $\mathrm{PP}$, of rapid inhibition (mainly by oversaturation of the photosynthetic apparatus and photooxidation, reduction in its carbon fixation capacity or photorespiration processes) and slower repair (Samuelsson et al. 1985), was not significant in autumn or in winter (see below). According to Behrenfeld et al. (1993), because of the difficulty in extrapolating laboratory results, the importance of UVB in photosynthesis is confounded. The effects of PAR and UV that occur simultaneously (Cullen \& Neale 1993) and the mitigation of long-term effects by photoadaptation and photorepair (Karentz et al. 1991a) should be clearly distinguished. 


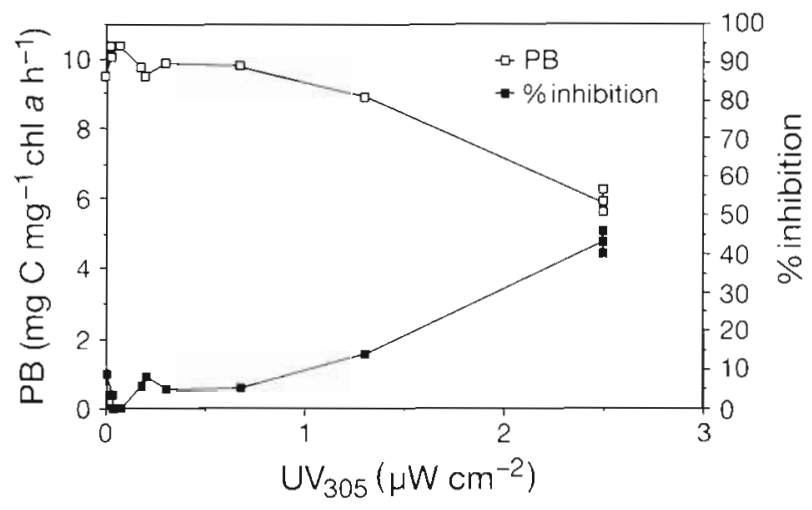

Fig. 5. PB of the April 1993 surface sample exposed to constant PAR $\left(2614 \mu \mathrm{W} \mathrm{cm} \mathrm{cm}^{-2}\right)$ in an UV gradient of 10 intensities provided by a fluorescent UV lamp centered in $313 \mathrm{~nm}$. Percentage inhibition is with respect to control values (zero UV) of the same data

\section{Surface and subsurface spectral UV changes}

From this survey of different UV bands, it can be seen that at $30^{\circ} \mathrm{S}$ there was not only an increase in the surface irradiance, but also a shift in the spectral composition of UV in the spring, when UVB showed the greatest increase. Use of the $305 \mathrm{~nm}$ band as an indicator of UVB is supported by measurements made in Antarctica, where a significant correlation was found between absolute values of $305 \mathrm{~nm}$ and total UV measurements using YESDAS equipment (Cabrera \& Pizarro 1994). Comparing the mean of $305 \mathrm{~nm}$ (normalized to PAR) in June with those found in April and October, there was an increase of 34 and $130 \%$ respectively (Fig. 2b). Changes at $340 \mathrm{~nm}$ during the year were not more than $19 \%$. In comparison to Vincent \& Roy (1993), who found UVB be to $0.8 \%$ and UVA to be $8 \%$ of PAR, in our study UVB was $0.4 \%$ and UVA was $11 \%$ of PAR. Only one major discrepancy was found, related to the percentage of UVB from UVA: $3.7 \%$ compared with $20 \%$ in Vincent \& Roy (1993).

In the water column in these upwelling areas, $Z_{\mathrm{UV} 308 \mathrm{~nm}}$ varied only $2.8 \mathrm{~m}$ between autumn and winter. This was the case even when considering the variability of $\int_{0}^{30} \mathrm{chl}$ a (6.9 to $\left.50.6 \mathrm{mg} \mathrm{m}^{-2}\right)$ and absorbing compounds within the upper $15 \mathrm{~m}$ (0.40 to 3.31 absorbance units) (Table 1 ). The mean $k_{308 \mathrm{~nm}}$ was $0.349 \mathrm{~m}^{-1}$ in autumn and $0.289 \mathrm{~m}^{-1}$ in winter. Jerlov (1950) reported that UV at $310 \mathrm{~nm}$ was reduced by only $14 \%$ per $1 \mathrm{~m}$ depth ( $k=0.15 \mathrm{~m}^{-1}$ ) in clear waters in the eastern Mediterranean. Armstrong \& Boalch (1961) found regional and seasonal differences similar to those we suggest for the study area. Smith \& Baker (1978) showed $k$ values at $310 \mathrm{~nm}$ that varied between $0.10 \mathrm{~m}^{-1}$ for open ocean waters and $0.38 \mathrm{~m}^{-1}$ for moderately productive waters $\left(0.5 \mathrm{mg}\right.$ chl $\left.\mathrm{a} \mathrm{m}^{-3}\right)$. This is also similar to the values higher than $0.30 \mathrm{~m}^{-1}$ for $308 \mathrm{~nm}$ which are reported here (see Table 1).

Under severe ozone depletion, UVB levels would be higher only in the upper fraction of the euphotic zone. Nonetheless turbulence in the mixed layer has to be taken into account, especially in upwelling areas where the radiation field regime for displaced phytoplankton is constantly changing.

\section{UV absorption}

Sufficient evidence exists about microalgae synthesising UV-absorbing compounds (Carreto et al. 1990. García-Pichel \& Castenholz 1993, Vincent \& Roy 1993). In this study, it was found that in 2 to $6 \mathrm{~h}$, medium latitudinal phytoplankton changed the 330-340/665 absorbance ratio 4 -fold. In situ, this ratio was 1.4 times higher in surface water compared with the $12 \%$ light intensity depth (Fig. 3). The same was shown by Yentsch \& Phinney (1989) for water columns with 2 different dynamics, one stratified and sunny weather and the other mixed and cloudy skies. These authors attributed large increases in the short-wave attenuation to the presence of UV-absorbing compounds.

The analysis of the spectral penetration of UV showed that 330-340/665 absorbance ratios were correlated to $k_{308 \mathrm{~nm}}$, indicating the presence of UVabsorbing compounds. It is surprising that these types of protecting compound absorb at wavelengths at which the relative DNA damage per quantum is small (Vincent \& Roy 1993). Not dismissing its relevance for other targets, this mechanism should be sufficient to cope with mean environmental stress.

The strong nonlinear correlation between absorbance and chlorophyll found by Yentsch \& Phinney (1989) speaks for the inclusion of ecological factors in ocean physics. In the present work, short-wavelength attenuation was found to be correlated with chlorophyll and other absorbing substances. Nevertheless, phytoplankton composition and cell geometry, gelbstoff and detritus may cause variability in the correlation of $k_{U \vee n m}$ with phytoplankton biomass and therefore caution is advisable when using $k_{308 \mathrm{~nm}}$ as an indicator of biomass concentration.

\section{Photosynthesis}

The nonsignificant difference of $P B_{\max }$ between treatments (on-deck $P$ - $I$ experiments), while screening UV irradiance in autumn and winter, suggests either that environmental stress was not sufficiently high or that microalgae can cope with it. Helbling et al. (1993), by means of in situ measurements with the same autumn 
sample from Montemar (9 March 1993), concluded that the effect of UV on integrated PP in a euphotic zone of $14 \mathrm{~m}$ was less than $3 \%$. Prézelin et al. (1993) proposed that lower sensitivity to UV inhibition during parts of the day is related, among other factors, to a diurnal increase in photoprotective screening.

In winter, at a mean dosage rate of PAR during $4 \mathrm{~h}$ higher than $6000 \mu \mathrm{W} \mathrm{cm} \mathrm{cm}^{-2}$ in the $<380 \mathrm{~nm}$ treatment (glass bottles), a relative decrease of 22 to $29 \%$ was observed when $P B$ was normalized by $P B_{\max }$ (Fig. 4). This is probably consistent with different sensitivities due to species composition, adaptation to low mean PAR values in winter (June), or the need for different time periods to acclimatize. This low light adaptation agrees with the fact that the lowest $P B_{\max }$ were recorded in June (Table 2).

Differential response to simultaneously occurring PAR and UV should be evaluated in further extensive studies of upwelling events, using more sophisticated incubators (see Cullen et al 1992).

Since the amount of UVB irradiance in the light limited portion of the water column is insignificant, it may be enlightening to focus on diminution of $P B_{\max }$. Under an experimental UV gradient and saturating PAR, maximum photosynthesis $\left(P B_{\max }\right)$ was inhibited only at a dosage rate that was measured in situ at less than $3 \mathrm{~m}$ depth at $30^{\circ} \mathrm{S}$ and less than $1 \mathrm{~m}$ depth at $33^{\circ} \mathrm{S}$ (data not shown), and because we didn't take the reflection into account, even this shallow depth may be an overestimation

Acknowledgements. We thank Osvaldo Ulloa and anonymous rewiers for helpful comments to the manuscript. Thanks also to C. Fernandez for the drawing and to L. Alexander and $T$ Ureta for help in editing the English version. This study was funded by a Chilean National Grant (FONDECYT 1143), the Development Program in Marine Science of the University of Chile and the Swedish-SAREC/Chile-CONICYT Grant for JGOFS-Eastern Boundary Current Study. Sampling and laboratory facilities for the work at Montemar were provided by Sergio Avaria at the Oceanology Institute, University of Valparaíso, and Bóris Ramirez at the Catholic University of Valparaíso, whose support is gratefully acknowledged.

\section{LITERATURE CITED}

Armstrong FAJ, Boalch GT (1961) The ultra-violet absorption of sea water. J mar biol Ass UK 41:591-597

Behrenfeld M, Hardy J, Gucinski H, Hanneman A, Lee H II, Wones A (1.993) Effects of ultraviolet-B radiation on primary production along latitudinal transects in the South Pacific Ocean. Mar environ Res 35:349-363

Cabrera S, Pizarro G (1994) Radiación UV en Isla Rey Jorge $\left(62^{\circ} \mathrm{S}, 58^{\circ} \mathrm{W}\right)$ durante la disminución de ozono estratosférico antártico 1992. Ser Cient INACH Chile 44:39-51

Carreto J, Carignan M, Daleo G, De Marco S (1990) Occurrence of mycosporine-like amino acids in the red-tide dinoflagellate Alexandrium excavatum: UV-protective compounds? J Plankton Res 12:909-921

Cullen JJ, Lesser MR (1991). Inhibition of photosynthesis by ultraviolet radiation as a function of dose and dosage rate: results for a marine diatom. Mar Biol 111:183-190

Cullen JJ, Lewis MP (1988) The kinetics of algal photoadaptation in the context of vertical mixing. J Plankton Res 10(5): 1039-1063

Cullen JJ, Neale PJ (1993) Quantifying the effects of ultraviolet radiation on aquatic photosynthesis. In: Yamamoto HY, Smith CM (eds) Photosynthetic responses to the environment. American Society of Plant Physiologists, Rockville. $M D, p$ 45-60

Cullen JJ, Neale PJ, Lesser MP (1992) Biological weighting function for the inhibition of phytoplankton photosynthesis by ultraviolet radiation. Science 248:646-650

Falkowski P, La Roche J (1991) Acclimation to spectral irradiance in algae. J Phycol 27:8-14

Fleischmann $E$ (1989) The measurement and penetration of ultraviolet radiation into tropical marine water. Limnol Oceanogr 34:1623-1629

Fonseca T, Farias M (1987) Estudio del proceso de surgencia en la costa chilena utilizando percepción remota. Invest Pesq (Chile) 34:33-46

García-Pichel F, Castenholz R (1993) Occurrence of UVabsorbing, mycosporine-like compounds among cyanobacterial isolates and an estimate of their screening capacity. Appl environ Microbiol 163-169

Helbling EW, Avaria S, Letelier J, Montecino V, Ramírez B, Ramos M, Rojas W, Villafañe V (1993) Respuesta del fitoplancton marino a la radiación ultravioleta en latitudes medias. Rev Biol mar Valparaíso 28(2):219-233

Helbling EW, Villafañe V, Ferrario M, Holm-Hansen O (1992) Impact of natural ultraviolet radiation on rates of photosynthesis and on specific marine phytoplankton species. Mar Ecol Prog Ser 80:89-100

Holm-Hansen O, Helbling EW (1993) Polyethylene bags and solar ultraviolet radiation. Science 259:534

Jassby AD, Platt T (1976) Mathematical formulation of the relationship between photosynthesis and light for phytoplankton. Limnol Oceanogr 21:540-547

Jeffrey S. Humphrey G (1975) New spectrophotometric equation for determining chlorophylls $a, b$ and $a_{1}$ in higher plants, algae and natural phytoplankton. Biochem. Physiol Pflanz 167:191-194

Jerlov NG (1950) Ultra-violet radiation in the sea. Nature 166: $111-112$

Jokiel P, York R (1984) Importance of ultraviolet radiation in photoinhibition of microalga growth. Limnol Oceanogr 29:192-199

Karentz D, Cleaver J, Mitchell D (1991a) Cell survival characteristics and molecular response of Antarctic phytoplankton to ultraviolet-B radiation. J Phycol 27:326-341

Karentz D, McEuen FS, Land MC, Dunlap WC (1991b) Survey of mycosporine-like amino acid compounds in Antarctic marine organisms: potential protection from ultraviolet exposure. Mar Biol 108:157-166

Kullenberg $G$ (1982) Note on the role of vertical mixing in relation to effects of UV radiation on the marine environment. In: Calkin J (ed) The role of solar UV radiation on the marine ecosystem. Plenum Press, New York, p 283-292

Lorenzen C (1979) Ultraviolet radiation and phytoplankton photosynthesis. Limnol Oceanogr 24:1117-1120

Neori A, Holm-Hansen O, Mitchell BG, Kiefer DA (1984) Photoadaptation in marine phytoplankton: changes in spectral absorption and excitation of chlorophyll a fluorescence. Plan Physiol 76:518-524 
Prézelin B, Boucher NP, Smith R (1993) Daytime kinetics of UVA and UVB inhibition of photosynthetic activity in Antarctic surface waters. In: Yamamoto HY, Smith CM (eds) Photosynthetic responses to the environment. American Society of Plant Physiologists, Rockville, MD, $p$ $150-155$

Prézelin B, Smith R (1993) Polyethylene bags and solar ultraviolet radiation. Science 259:534-535

Samuelsson G, Lönneborg A, Rosenquist E, Gustafsson P, Öquist $G$ (1985). Photoinhibition and reactivation of photosynthesis in the cyanobacterium Anacystis nidulans. Plant Physiol 79:992-995

Smith R, Baker K (1978) Penetration of UVB and biologically effective dose-rates in natural waters. Photochem Photobiol 29:311-313

Smith R, Baker K (1980) Biologically effective dose trans-

This article was submitted to the editor mitted by culture bottles in ${ }^{14} \mathrm{C}$ productivity experiments. Limnol Occanogr 25(2):364-366

Sokal R, Rohlf FJ (1981) Biometry, 2nd edn. WH Freeman and Co, San Francisco

Vernet M, Brody EA, Holm-Hansen O, Mitchel BG (1994) The response of Antarctic phytoplankton to ultraviolet radıation: absorption, photosynthesis, and taxonomic composition. Antarct Res Ser 62:143-158

Vincent W, Roy S (1993) Solar ultraviolet-B radıatıon and aquatic primary production: damage, protection, and recovery. Environ Rev 1:1-12

Yentsch ChS, Phinney DA (1989) A bridge between ocean optıcs and microbial ecology. Limnol Oceanogr 34(8): $1694-1705$

Zar JH (1984) Biostatistical analysis, 2nd edn. Prentice Hall, Englewood Cliffs, $\mathrm{NJ}$

Manuscript first received: September 9, 1994

Revised version accepted: January 9, 1995 